\title{
Moving beyond psychiatric diagnosis and the medical framework towards social recovery: an interview with Jim van Os
}

\author{
Para além do diagnóstico psiquiátrico e do \\ modelo médico, na busca pelo "recovery" \\ social: uma entrevista com Jim van Os
}

Rafaela Zorzanelli*1, Claudio E. M. Banzato*2,

792

There is a growing realization in the field of psychiatry that we are unable to free ourselves of the constraints imposed by our concepts, as well as to move beyond them. Thus, the field demands not only more robust empirical evidence but also a more sophisticated conceptual framework, which would allow for critical and innovative thinking to conceive and to build better models of mental health care. In this spirit, we present a very thought-provoking interview with Dutch psychiatrist Jim van Os, encompassing biographical issues from his academic background as well as his ideas on recovery and the Dutch experience of the recovery colleges as a "shadow mental health system" in the Netherlands. Adopting a critical stance on psychiatric diagnosis and the validity of group-level comparisons in evidence-based psychiatry, and in line with the ideals of the recovery movement, van Os points out that the process of healing should surpass symptom reduction. For him, it should take into account the long-term process of developing resilience,

${ }^{* 1}$ Universidade do Estado do Rio de Janeiro - UERJ (Rio de Janeiro, RJ, Brasil).

*2 Universidade Estadual de Campinas - Unicamp (Campinas, SP, Brasil). 


\section{ARTIGOS}

learning to deal with suffering through interactions with other people, building up new perspectives, goals, and existential purposes. In other words, he emphasizes the idea of social recovery and favors the thought that mental health professionals should try to "help people to relate better to their mental variation and offer them ways of doing that differently."

Key words: Psychosis, transdiagnostic dimensional approach, social recovery, recovery colleges

Advancing the agenda of providing more meaningful and effective mental health care to those in need remains one of the greatest challenges of our time. Indeed, much of the difficulty hinges on the way we conceptualize mental suffering and the framework we adopt to deal with it. One of the primary disciplines in charge of it, psychiatry, despite the multiple competing traditions within this specialty, is strongly dominated by the medical disease-entity model, with discrete diagnostic categories and assumed (though elusive) neurobiological underpinnings at their core. The prominence achieved in the mental health field by the DSM and the ICD in that regard speaks for itself. However, criticism of that approach has also been loud and sound. There is a growing realization that perhaps we are somehow entrapped, unable to free ourselves of the constraints imposed by our concepts, as well as to move beyond them. Thus, the field demands not only more robust empirical evidence but also a more sophisticated conceptual framework, which would allow for critical and innovative thinking to conceive and to build better models of mental health care.

It is in this spirit that we present here a very thoughtprovoking interview with Jim van Os, Professor of Psychiatric Epidemiology and Chairman of the Division Neuroscience at Utrecht University Medical Centre, Utrecht, The Netherlands, and Visiting Professor of Psychiatric Epidemiology at the Institute of Psychiatry, London, UK. Professor van Os is an extraordinarily accomplished and well-recognized researcher and has published over a thousand articles in the most influential scientific journals, receiving dozens of thousands of citations. 
His scientific contributions span over several key topics of psychiatry, such as the notion of a psychosis continuum in the general population and risk factors for psychosis. Since 2014 he is on the Thomson-Reuters Web of Science list of the world's 'most influential scientific minds' of our time, and over the period 2009-2015 was the coordinator of a €12M EU FP7 IP project on gene-environment interactions in schizophrenia. Professor van Os currently leads the Division Neuroscience at Utrecht University Medical Centre and is the founder of a public health service for psychosis in the Netherlands. He is also actively involved in mental health reform in the Netherlands as well as in Science in Transition, a movement that makes an effort to ensure that scientific research and technical-medical outcomes could be used to fit in with the living environment and the patient's values. The patient participation is a relevant strategy in this process and a significant concern in healthcare.

It is worth pointing out that Professor van Os was trained both as a psychiatrist and as an epidemiologist, and this explains his taking into account broader perspectives for the phenomena studied in the sense of not being restricted to clinical samples. It should also be stressed that he was trained in medicine and psychiatry in countries as culturally and socially diverse as the Netherlands, Indonesia, France, Morocco, and the UK. As he says at the beginning of the interview, it became clear to him the extent to which the concepts in psychiatry varied in these different traditions, and the crucial role played cultural values in psychiatric thinking.

Professor van Os importantly acknowledges the immense variability of mental states within and between persons, and for him, this is critical for rejecting in psychiatry the primacy of group-level comparisons, which underlie evidence-based medicine. Accordingly, he is skeptical about the reach of the symptom-reduction model due to the weak connection with which the person is experiencing. Instead, he favors the idea that mental health professionals should try to "help people to relate better to their mental variation and offer them ways of doing that differently." That would have an impact on stigma as well "because stigma, basically is about people not being able to make the connections between their own psychology and symptoms of madness."

Finally, we want to draw the readers' attention to the powerful idea of social recovery, which van Os emphasizes, and distinguishes from both clinical and existential recovery. Jim van Os draws on the goals of the recovery movement, which started in the 1990s, defending that "a person with severe mental illness wants and needs more than just symptom relief" 
(Anthony, 1993, p. 11). So, the idea of being in recovery is described "as a deeply personal, unique process of changing one's attitudes, values, feelings, goals, skills, and/or roles. It is a way of living a satisfying, hopeful, and contributing life even with limitations caused by illness" (Anthony, 1993, p.15) Hope is also a word that we will find quite often in van Os' interview. And hope was a crucial ingredient in the recovery process since the beginning of its seminal texts, as "[a] tiny, fragile spark of hope appeared and promised that there could be something more than all of this darkness" (Deegan, 1988, p. 14). Hope, although a fragile spark, is, nonetheless, the most real trigger to action. Lastly, according to Davidson et al. (2016, pp. 33-4), the recovery movement has also been built based on scientific evidence that challenged the view of schizophrenia as a life-long disease heading inevitably to progressive deterioration and decline and showed instead heterogeneous trajectories in course and outcomes. Thus, the critical view of the mainstream psychiatric diagnosis and the belief in people engaging in meaningful lives were cornerstones of this perspective, in which the work of van Os is situated. The Dutch experience of the recovery colleges, funded by the social security system instead of being supported by the traditional mental health system, raises the so-called "shadow" mental health system — an innovative and worth knowing idea. For all these reasons, we expect the reader to profit from the lively and stimulating exchange between Rafaela Zorzanelli and Jim van Os, which took place on October 3, 2019, in Utrecht.

\section{Question 1}

RZ: I'd like to start with a general question about your background. I think it's fair to say that many of the ideas you have published (and publicly debated) deeply confront and consistently criticize many concepts taken for granted in the mainstream current of psychiatry (for instance, some cornerstones of evidence-based medicine, diagnosis as a monolithic label, the idea of "high risk" mental states, the symptom-reduction model, and so on). The interesting thing is that you combine this epistemologically critical position with an existential approach, so to speak, which emphasizes ideas such as identity, meaning, purpose, and community. In your approach, patients' needs are always taken into consideration in the process of dealing with mental suffering. How did your academic background contribute to building up your current ideas on psychiatry? 
JvO: So, initially, my academic background was actually influenced by my career in psychiatry because when you do a training in psychiatry, you do an academic post-graduate training where you are given concepts and science that you can use to build your clinical practice. And this is very much also an introduction into a culture. And when I was a psychiatrist, I was given the opportunity also to become an epidemiologist when I was in England at the London School of Hygiene and Tropical Medicine. And I think that's had an important effect because that was another post-graduate academic career, an MSc. And the concepts we were given there were extremely critical in principle of anything because epidemiology is basically the science of being very critical and very methodological or very careful in building scientific concepts and applying them to the population. So the interesting thing was that the UK government's had decided that particularly the area of psychiatry had a need for further training in epidemiology, that they needed more clinical practitioners to become educated in epidemiology and after the epidemiology training I understood why because then if you apply epidemiology to psychiatry the notion you get actually is that psychiatry is very much about really not knowing very much. And that then knowledge is built based on the tradition on the one hand, and science in the field of psychiatry, on the other hand. But the problem is that the science in psychiatry is very soft, very difficult to replicate, very much based on what's in vogue, in terms of the current theory. And the scientific traditions are also not really based on science but also sort of mixture of the old German and French tradition of trying to decide what is mental suffering and how do we go about it, you know, classify it and treat it in the tradition of medicine. So epidemiology really helped me to become really skeptical about all this. And the second part of my academic career was that that helped. I first was trained in the Netherlands as a general physician in medicine, and then I went to Indonesia. And then, I went to Morocco, and I trained in France in psychiatry in Morocco also in psychiatry, and then I came to the UK and did the rest of my training there. And I was a little bit bewildered by - this was actually my first article in 1993, in the British Medical Journal about the concept of schizophrenia in France and in the UK. And I was very surprised that it was completely different in France and in the UK and that in Morocco it was a sort of a combination between old Arabic concepts of medicine and the French cultural concepts of psychiatry to modern and psychoanalytical concepts that were sort of used there and it was very, very confusing for ... I think. And also in Indonesia a mixture of olds traditional values. Parts Ancient Indonesian and parts Muslim cultural concepts and parts modern Dutch society and modern medicine concepts. Those were the 
old colonial values. So I began to see that actually the thinking in psychiatry is very much guided by cultural values that are considered science and hard knowledge, but in fact it is a way of filling the gap of not knowing very much. And that's what makes psychiatry so interesting, I think. It is really about the clashes of values and fear of not knowing about something as important or frightening as madness. And for some reason, traditional medicine has become the dominant tradition of dealing with madness and mental variation. So it's been drawn into the area of clinical medicine, which is a big thing. Because then things become medicalized and you look to mental suffering through the prism of clinical medicine, and that's what the important European tradition I think that it has contributed to the state of affairs where we are now. Which elsewhere in the world has as let to clashes between different values and ways of looking at mental suffering and mental variation in general. And a third thing was academic, was that I became a pupil, I became somebody who from nearby has experience as a relative with mental illness. So many of my relatives in my own family close family first-degree relatives struggled with addiction, with psychoses, with manic depression. So it gets a different sense of how people go through the system. But not from looking, you know, have a sort of vertical communication but horizontal. So that's what led me to actually also start horizontal communications with patients, users in my own work. So we started to sort of collaborating at a horizontal level as partners in looking for knowledge. So, me having professional knowledge and uses having experiential knowledge and we sort of started. This was when I was in Maastricht. We started to experiment with "well, what if you bring to sources of knowledge together? What sort of conflicts do you get what sort of interesting insights to your get? Does it match? Can it exist alongside each other? Can it work together in achieving goals? What should change? And these were very interesting time, so it wasn't really research. But it was a sort of cultural activism, I think. Because of all these questions I had and different experiences in academia and personally.

\section{Question 2}

RZ: I understand that the paper you co-authored, "The evidence-based group-level symptom-reduction model as the organizing principle for mental health care: time for change?" (van Os et al., 2019), is a kind of programmatic paper for mental health services that agree with this kind of approach. You 
point out many limitations of the current mental health systems in many countries in the world, but you also offer a few pathways and suggestions which could help mental health professionals and patients to overcome these limitations. One of the topics that you have approached in your most recent papers - and also in the aforementioned one - is a kind of criticism of EBM (evidence-based medicine). And it seems to me that one of your focuses is to point out how the criteria of what is considered a good outcome in EBM, such as the symptom-reduction principle, can be disconnected to patients' primary needs in the social and existential domains or even the experiential knowledge of sufferers. Could you share with us some of your ideas on this issue?

JvO: So, first of all, there's the scientific epidemiological criticism, and that is that mental states as outcomes are extremely variable within and between persons. And statistically, the argument is that group-level comparisons in mental health using symptom measures are not readily applicable to the individual because the variability within persons of mental states is such that it escapes the group tendencies. So what is good for the group doesn't necessarily apply to the individual. This is true for orthopedics and cardiology but much more true for mental health. So it makes evidencebased psychiatry in that respect to a degree irrelevant because the end is one situation that tends to escape group comparison statistically. But more important, I think is the difficulty we have in defining what is the outcome we're trying to influence. And because we have been placed within medicine and psychology has very much adopted the medical approach. We are faced with a situation that we come with standardized improvements of symptom reduction measured with psychometric scales. And the interesting thing is that people who have dealt with mental illness will tell you that dealing with mental suffering is a process of years, in which you sort of try to learn to create space through a change in perspective such that it is not only filled with illness and the concept of illness which often is conveyed, you know, by the interactions with medical professionals because they tell you've got a brain disorder, etc. So all your space is filled with illness, and the process of recovery is that you learn through a very interesting process of turning points and insights and all sorts of interactions with people that you create free space around the illness for work for relationships, for perspective, for new goals. For an existential purpose that you felt very discouraged to even think about when you were completely in the field when you felt like "it's all about illness" and the person was disappearing. So this process of free space through the development of resilience. Resilience in the sense of 
connections with other people. Where your suffering is not just met with: "we have evidence-based guidelines, and now we're going to do this, and now we're going to do this". But interactions where your suffering is allowed to be and where you can connect with other people who have experience of such suffering or if they don't have the same experience, respect it. And have a way of dialoguing with you about your suffering, which is not necessarily "we're going to do something" which is very helpful for people because it creates connections to other people which are very important in the sense of the experience of the healing environment. So the other aspects of resilience are that there's an environment with hope. Not irrealistic hope, like we're going to cure, we're going to fix you, but more hope like you will one day be able to develop a perspective that life can be meaningful even if you have voices twenty-four hours, you know, tethering in your ears and saying all kinds of things about you. Also where there's an environment - very important - where there are professionals who will tell you look I can't fix you, but we can travel together, you know, I'm not going to let you go, I've got a few tricks like I got a few molecules, I've got a few psychotherapeutic techniques. I don't know, you know, exactly what they do because it differs from person to person, but we can try some. And we can see what works for you. It's a long learning process, very difficult; maybe there is something you can use. And you know I'm not going to let you go, I am going to support you, I'm going to try that. So that is hope. It's also the professional who can add value, perhaps in that sense. And the other aspect of resilience is that there are literally places where you can go. So that you're not lonely but literary that are places that have a sense of community where you can go, and nobody will ask for your name or your number, or you have to register or they talk about your diagnosis. But places that are purely there to help you with: "how am I going to go about it"? Developing resilience, healing, and dealing with my suffering. So they are called Recovery Colleges or Herstel Academisch in Dutch. Very interesting places because they are, at least in the Netherlands, completely disconnected from the traditional mental health care yet. And they've got different systems or finance. They are not within the medical system; they're within the social system. So the social system funding its use and there are places where you can go you say while my name is Piet, I'm addicted, I'm hearing voices and I'm suicidal. You know, and then somebody will say: "ok, Piet, come in. Have a coffee. You don't have to give us your name. We're not going to examine you; there is no diagnosis, there's no guidelines, there is no evidence-based medicine. There is no inspection whether we are working safely and according to the guidelines. 


\section{RZ: No doctors?}

JvO: No doctors, nothing. "Go and have a cup of coffee, and by the way, my name is Barbara, and if your interested, in an hour, I'm starting a group because it's about education here, we offer education". And the purpose of the group is to offer each other education about why should I come out of bed in the morning and not kill myself. That is the purpose of our group. And I'm the facilitator because I was there. So, you know I know something about it, and I'm going to be looking at this from an educational perspective. So these places are very popular. People can come there, have all sorts of educational activities like voice-hearing groups. They are now thinking of developing peer support in open dialogue so that if there's a crisis in the community, they will go there and solve the crisis or stay with people and talk to them from the perspective of meaning about the crisis and, with relatives or friends or people in the network. If you're on a crash for a few days, they've got the retreats so that you can crash there. And be non-linear and your behavior for a few days over there. So then you will prevent that, if you're non-linear in your behavior, in your neighborhood somebody will call the police. And they wish you off to a mental hospital so that's a very interesting way of working. And very importantly, being in an area they provide social holding. So what you get is from the recovery college and their activities like open dialogue, their contacts with GPs, their contacts with locals, important people in the area. You can create a system of social holding which is very very difficult, but we desperately need social holders in the sense that a lot of people with severe mental illness display non-linear behavior. And it's very difficult indeed in a country like the Netherlands where everybody should be extremely linear and where everything is looked at from the perspective of neoliberal, you know, everybody creates his own purpose, and you can measure everything, and you can make everything work and possibilities are there for everybody, if you're non-linear you don't fit. So then it becomes very quickly, you're brought back to the mental health system. But if you have social holding so that people can have non-linear behavior. And it's dealt with by a buffer a network of peersupport explaining things, involving the family, involving the networks, the GPs, having retreats etc. and you can create social holding and prevent people from re-entering the mental health system. So this is now happening in the Netherlands, we have a shadow mental health system that is slowly being build in the social care domain completely off the radar, of the inspection of the evidence-based medicine and everybody else. And this is what I think is very, very interesting because nobody sees it yet. That this is a shadow mental health 
system that is being developed because the old one, people don't want to go there. There is now research showing that just the fact that if you go into the mental health system before you see anybody, you get a symptom rating scales sent to you because the ensure wants to measure the symptoms before and after the treatment. But that's also an intervention. It's telling people if you have mental suffering, it comes in the form of symptoms, and these symptoms are part of an illness. Therefore your mental suffering should be perceived from the perspective of illness. And the treatment is the reduction of the symptoms. So that's already an intervention, and I think it's a very dangerous intervention because lower mental suffering is existential. It's being in a wrong relationship, in the wrong job, perhaps or even living in the wrong society. You can suffer because of the neoliberal - I don't blame everything on neoliberalism, but some people suffer particularly young people because they see: "if I have to join this type of rat race where everything is measurable and neoliberal and everybody's making his own fates, but it has to be about success then maybe I'm not fitting". And you can become depressed and then you've told you've got a mental illness so this is not a good system, I think. It should be much more sensitive to that mental suffering is linked to context. And also to life history. So that's what we should be telling people if they enter the mental health system. But that's not possible because... So the shadow mental health system is exactly how we like it according to the existential model. And I think professionals can have a role if they become coaches to guide people through this shadow mental health system. And from a perspective of self use and empower self-management but also relationships offer these services to help them develop resilience to deal with this mental illness.

\section{Question 3}

RZ: In the context of your lecture "Technical psychology and psychiatry: everything under control?" (van Os, 2019), you talked about the process of dealing with mental suffering. You made a provocative statement: "There's no recovery", and you added: "Recovery is not about personal resilience but social resilience". According to your work, these tropes can be understood as linked to the ideas of chronic persistent vulnerabilities that tend to crop up over the course of life. So, dealing with mental issues is not so much a linear process of cure as a process of living with and beyond these vulnerabilities. Could you comment on this? 
JvO: Yeah, so, recovery doesn't exist in the sense of clinical recovery like you would fix a broken leg. That sort of fixing doesn't apply to mental suffering. So you have three types of recovery: you have clinical recovery, existential recovery, so repairing you're getting back perspective, really, and social recovery. You can sort of separate and perhaps a little bit some people are reluctant to do, but I think heuristically, it can be useful to see it in that way. And then things become much clearer so that you say, mental illness really as a construct is not very useful because scientifically it's about vulnerabilities. And, for example, the genetics of schizophrenia, the diagnostic construct of schizophrenia is very interesting because it shows that we all have thousands of genetic variants that contribute to the liability to become psychotic. So the genetics of schizophrenia shows that human genetic variation is about psychosis also. So it's part of normal human mental and genetic variation. So then you can say this type of mental variation can give rise to the experience of hearing voices for example. Hearing voices is not an illness. It's part of the human behavior repertoire, but it can make you ill if these voices, you know, are negative and are powerful, and you can't deal with them. So the mental variation itself is not an illness. It's part of our variation, but it can make you ill. And then you can learn, then learning to deal with it; you can uncouple the need for care from the experience so that you don't have a need for care anymore. So I think that's a very useful construct. So it means that we have to change the language and say things like susceptibility. Some people say psychosis susceptibility syndrome. But even that's of course perhaps too medical but as a transitional phase, I think it would be useful. And then you have to look at what needs we are recovering. So often what needs recovering and where professionals can help. It's not the experience itself, so taking away the voices but more how you relate to your mental variation, how you relate to your depression or how you relate to your suicidality or how you relate to your voices. Or your anxiety. What psychologists, psychiatrists nurses can do is help people relate better to their mental variation and offer them ways of doing that differently. So, for example, I had a patient with very very very severe depression. His father had committed suicide. He was afraid he would commit suicide as well. He felt very low, very suicidal. And what he did is he started monitoring his mood every day. Five times a day and he made graphs of that. He is very systematic. And he did it for eight years. And he saw his mood vary from day to day. And this is typically a turning point people describe in the recovery process he saw that his mood changed and that even when it was very low at one moment, it would always go up 
again. And that perspective gave him the insight of when "I'm very low, I think I will never get better I will go further down but in fact, it doesn't happen. I always go up again". So that insight is a turning point and made it possible for him to relate differently to the moment he was extremely low and because he was able to relate to it differently. His fear of suicide decreased. So this is what I find so extremely interesting. We know very little about how people develop these turning points. Turning points are then described, for example often like "I was ten years in a hospital, I was cutting myself all day I was listening to my voices. All I could think of is: I'm not allowed to exist until I met somebody who said '...".. So then often that is how turning points arise. Somebody says something, and it's not what they say particularly, but at that particular moment, people are able to hear for some reason what this person is saying what they were not able to hear a year ago. And then they develop an insight, a turning point and relate differently to there mental variation which is still there. And I think what I see in recovery colleges is that a lot of that is going on. People are talking to each other, telling each other about your experiences, sharing their experiences. And then voice-hearing groups, the same thing. Some people actually are able to change the power differential of how the voices interact with him and the power differential changes in the sense that the voices that were all-powerful are very slowly losing power. And the person creates some free space and has something to say about. The process of what a voice is saying and when and then that becomes a turning point for somebody else. To start trying to do the same thing. So if that is getting better from the existential recovery perspective, then the question becomes, how can evidence-based medicine contributed to that. And I think evidence-based medicine can perfectly relate to that. But it has to start with accommodating our language and our stands towards what we think we are seeing if we talk to somebody with mental suffering. You have to really change our glasses and change the diagnostic category evidencebased guideline treatment glasses from simply glasses that see another human being. It allows us to see the person and then analyze the perspective of the person in relation to the particular kind of mental suffering that is in their analysis. Analyze its relation to the context in terms of life history. And then say, "where do you want to go with your life?"; "And how are these experiences keeping you from going there"? And then what does she need to still go there in spite of these experiences, you have. So you have a completely different process of insurrection and diagnosis. 


\section{Question 4}

RZ: Still in this lecture, you said that "Clinicians make the difference, not prescriptions". How can we think about the difference a doctor makes in the context of the significant and growing informal network of online, self-help e-communities, app for people with a variety of mental health problems?

JvO: Yeah, yeah. So basically what I talked about was that if you analyze evidence-based psychiatry and evidence-based psychology, it's very interesting if you do the proper scientific analysis. It appears that the technical ingredients like the medications and the technical psychotherapies in terms of even the symptom reduction they bring about in randomized controlled trials are not brought about so much by the technical ingredients or the medications themselves but, only as a general component of a relationship that revolves around enticing the people to move towards change. And then, a treatment is a sort of a good thing, a sort of a rationale of a treatment you need in the ritual. But what causes the effect is to relationship enticing people to take steps towards change. If that is true, then that should be used. So theoretically online help in a one-to-one situation or with a chatbox, it's not going to be useful, and that's indeed what the evidence suggests. So you need, if you do things online, you also need to have a relationship somehow. So that's why we have created a community like PsychoseNet. We have now like 1,500.000 visitors a year. And it's a community in a sense where you can go and have our most popular places to forum and chat. And you can go there and interact with people and do the things you can do to build a relationship although it's more difficult often because it's online. But still, we create a sense of community like, "here you are and there's people here, and they blog and they write, and you can ask questions, and you can chat, you can do the forum". So we create a sense of community which is always less strong than a recovery college of course, but still, it's there, and still people make use of it. Because it can also be four o'clock in the morning and recovery college is closed. And you wanna chat, and you wanna go somewhere, and you will have the sense of "I am part of a bigger whole." And that is what we offer. And there, online interactions can help. So I'm against chatbox because I think they're dangerous. Because then if your suicidal and depressed and you think you're dealing with somebody and then all of a sudden you realize it's a chatbox) and then you ask the question "are you a chatbox?" And you get some vague answer. Than that can be very disappointing. So I think 
online, you can also have relationships. It's not as good as the real thing but still, you can do. You can use it as a complement to the recovery college as an extension of the recovery college to online extension, which is limitless because millions can go there. And also I think it's very important to have those kinds of things for people who have existential problems. Like you feel existentially depressed. You can go there, and other people can help, but it is not very severe. And other people can help you interpret what you're feeling. Because there's a lot of websites that invite you then to fill in a symptom measure, then they say "you scored higher six, so you're highly depressed." So I think that online community that can help you deal with "what is it that I'm feeling?", for example. Maybe you in the wrong job, the wrong relationship, etc. So prevents you from putting your mental variation in the context of the illness-based thinking of psychiatry. So for those people that could be very useful as well.

\section{Question 5}

RZ: You wrote in that paper I've already mentioned (van Os et al., 2019) that the attempts of DSM-5 and RDoc to conceptualize the idea of transsyndromal diagnosis did not go that far. What are the gains of thinking about trans-syndromal diagnosis?

JvO: Yeah, well, good question. So we think that anything that breaks the categorical barrier conceptually in something as dominant as the DSM or the ICD will help liberate people and psychiatry from the diagnostic confines through which they read other people, they interpret other people. So we think that if the DSM is presented as ... well, you know, can look at mental suffering in terms of having diagnostic boxes for classification. But scientifically, there is an argument for saying oh "it's just broad dimensions of mental experience of human mentation that can go from the very minor variations to extreme variation." So and that is a more useful way probably to follow people over time because things change. So that you don't have to think like first, you have a diagnosis of schizophrenia, and you have schizoaffective and then bipolar and borderline. And it changes over time. And people are bewildered and the family because they don't understand. They don't have that problem anymore because they just follow all the domains of symptoms change over time. And you learn people that, you know, these things change 
over time. And you're not a part of a group or a category. So to the degree that we need to think about symptoms because you can also argue: well, why focus on symptoms at all — which is also useful I think — but since we're still so dominant in doing that I think we need to realize that they're part of a dimensional system of human mentation. It will be a process of, an instruments of a cognitive debiasing of mental health professionals. So having a diagnostic manual that conveys a transdiagnostic dimensional approach is the best instrument for cognitive debiasing the mental health professionals and in extension of the mental health professionals, society at large. Because society if you use mental variation through a prism of what we the professionals are saying it is about. So the professionals say "well, you know it's a part of human mentation, and it goes in all directions than people will be able to see that, as well, which would be helpful I think. Because stigma, basically is about people not being able to make the connections between their own psychology and symptoms of madness. And the word schizophrenia doesn't help because she can't recognize it in terms of your own psychological mentation.

\section{Question 6}

RZ: In the paper "Schizophrenia" does not exist, published in 2016 in the British Medical Journal (van Os, 2016), you wrote that "In March 2015 a group of academics, patients, and relatives published an opinion piece in a national newspaper in the Netherlands, proposing that we drop the "essentially contested" term "schizophrenia," with its connotation of hopeless chronic brain disease, and replace it with something like "psychosis spectrum syndrome" (p. 352). You were talking about the piece "Laten we de diagnose schizofrenie vergeten" (van Os et al., 2015). What were the intellectual and academic circumstances that enabled that group to publish that in a newspaper in 2015, and what are the major impacts of what you and your research team have been publishing in the international debate on the idea of psychosis spectrum? What is to be gained by replacing the concept of schizophrenia with the psychosis spectrum?

JvO: So, very interesting. I think the momentum was build because, like in Japan there was a movement of parents and patients that wanted to have the same thing that happens in Japan. Where schizophrenia was replaced 
by a broad notion of vulnerability. And the patient organizations have been writing to the DSM workgroup I was a member of saying "well you've got the scientific name psychosis susceptibility syndrome. So why don't you do that?" These were Dutch patients. And we'll found each other at some stage and say "well since DSM can't change we can change the use of language. So we proposed this. And the newspaper published it, and it gave rise to a huge academic debate. Of course that's very useful because that's what we wanted, we wanted to have these debate and we had psychoseNet. And now we see that after the face of debates there's reconciliation. And now people are talking about psychosis syndrome, psychosis susceptibility syndrome, psychosis spectrum syndrome. And the use of words like schizophrenia is decreasing very, very rapidly. So we built on the international momentum around DSM-5 and brought about this change which is very nice, and now we get ICD-11. ICD-11 was greatly delayed but that helps because there are now busy doing research along these lines. They have just done a huge study in France. It (is) still submitted, but I'm refereeing it. No, no, sorry, in fifteen countries all over the world including Mexico and I think, Brazil where it just asked patients and their carers: "is schizophrenia helpful as a diagnosis?"; "Is depressive episode helpful?" And basically, what they find is that patients are saying "not really". And if given a chance to invent another name nobody comes with the schizo root anymore. So I think this is very important. So I think this is just part of international momentum that is building up to modern eyes psychiatry. To the fear of psychiatry of leaving its nineteenth century roots. Because we still talking about Kraepelin, you know, and the old manic depression schizophrenia divided, it was invented in Germany a century and a half ago. Why are we still talking about that? That's the interesting thing. So, I think what we are doing there is trying to entice people to liberate themselves from old knowledge that is not useful anymore. But we're very attached to it because there is nothing better yet. We are criticized - by the way, maybe it is good to mention - we are criticized for a sort of bias. It's a very ugly word, so it's the same bias to low expectations bias. So that people say well, because you have such low expectations of biological research you are treating everything that comes from their as not hopeful and not useful. And you are biased. Because there have been no great progress you say it's never going to happen. But what we are saying, in fact, I think is that we are more from the open science movement and the science in transition movement, that we we say. It's not that we don't need science. We need better science. And it's no use to do case-control studies, you know, and looking for differences because of the differences hundred schizophrenia 
patients, hundred controls. Everything differs because of the many possible factors, of course, but that's not going to help us understand and better treat mental suffering.

\section{Question 7}

RZ: Your work has contributed a lot to shedding light on the large number of publications over the last two decades that are building upon the idea that "ultra-high risk" or "clinical high risk" means a "transition" to a psychotic disorder, or in other words, the "implicit suggestion that all or most psychosis leads to schizophrenia" (van Os \& Guloksuz, 2017, p. 204). Can the critique of the misleadingly binary concepts of "risk" and "transition" also be understood as a wider critique of the benefits of early interventions in mental health issues?

JvO: Yes. Yes, I think so because basically it's about if you're a doctor then you see everything through the prism of illness, so you think everybody we'll see is potentially a patient. And what we like is, because we only see patients, we can only think of people in terms of being pre-patients or being at risk. So we like to say well: "he always got a few symptoms but not quite a thing. So let's look for all high-risk patients and treat those because then they won't be ill." And that's logical from the medical perspective, but from the societal perspective, you have a different view because then you know there's the prevention paradox. Prevention paradox is that it's not very useful to try to find people who have high-risk because the impacts on the prevalence of illness in the population will hardly change. And that's because most people who become ill don't belong to the high-risk group. They go through a low-risk group process towards illness. So if you want to impact illness and morbidity force of an illness in the population you need to treat well people. And you need to prevent them from becoming exposed to risk factors that you can reduce in the population. So if you can eradicate alcohol then there won't be any more alcoholism, and then we don't need to chase people in GP practices saying "are you at a high-risk?", "are you drinking a little bit too much? Let's treat you." It won't have much effect. But of course, if you are a patient and you're on your way to develop psychosis or schizophrenia, than your parents and your friends will probably be grateful if somebody could treat you in an early stage that you're prevented from going there. So 
that should also be a possibility of course. But it's within a good scientific framework. And that's what we think criticizing. So we think that most mental illnesses and indeed, most medical illnesses have to do with things like social inequality and poverty. And all sorts of societal circumstances that we can change for the better. And then reduce illness. So you can reduce much, much, much more suffering focused on society and things like diet and lifestyle or social inequality and poverty. And violence and things like that, you can reduce much more than having a medical approach towards finding high-risk people and treat them very early and prevent them from becoming ill. That's closing your eyes also for a little societal stuff that's going on. That we, as doctors, also should be concerned about and try to change through the process of politics and public health impacts and measurements.

\section{Question 8}

RZ: This last question is about diagnosis and mental health categories, especially in the two main classification systems we have (ICD and DSM). Diagnosis and mental health categories are tricky concepts. On the one, hand, diagnosis can help people access mental health services, they can be useful for helping describe mental suffering in a common language and can therefore be useful for research purposes. They help reimbursements, monitoring, building up public health policies and evaluating the outcomes of mental services. On the other hand, they can imprison mental suffering and mental sufferers in stigma or in unsatisfactory descriptions of their suffering. So, can we also understand your powerful critique of the concept of schizophrenia as a critique of the general process of standardizing categories and diagnoses that regulate our current mental health system?

JvO: Definitely. So I think if you look at it from a very pragmatic point of view than what is important is that if somebody presents with mental suffering and ask for help. That we find language is maximally conducive to worth helping that person recover. So then I think if the question becomes "is the use of diagnosing illness categories and that use of language in somebody who presents mental suffering, is that's really the best way to send people on their way towards recovery?" Then I think, if you look at the research, I think the answer is no. So, then pragmatically, the question becomes what is the language then that you can use? That's 
the most important thing. Because there's also administrative and other uses of language but surely the most important thing is the person him or herself. I think then, it's trying to find language that provides unique inroads towards that person's experience and their understanding of them. Because then you help the person to go to worse experiences and develop strategies of resilience. And then if you say "well, that's all very well buts do you really want a language and formulations of mental suffering that is completely different for each and every person entering the mental health system? Then I would say, of course, we have a need for the categorical perception that's also inbuilt in the human psyche. We see categories. And we have a need for categories so then I would say "well, if you need categories - but helping the person's is at the level of a unique formulation, then why don't you take categories that are very broad and show that it's about a spectrum that goes from normal mentation too severe mental suffering? And help the person place their unique aspects of mental suffering somewhere along that spectrum". Seldom you're somewhere on the spectrum, but it also has unique features that we need to explore because every person is different. So that's what I like in the DSM-5 autism spectrum because now for the first time - and addiction in the DSM-5 - is also an spectrum - it's just eleven items, criteria, and the more you have, the higher you are in the addiction spectrum. And that's really saying "oh, there's a spectrum of human mentation and that we call autism". And it depends on the circumstances but it can give rise to problems so maybe if we need to classify your thing, maybe we need to look there. Somewhere between autism spectrum and psychosis spectrum. And that's a different way of talking about it so it's categorical, but it's not so clearly defined, you can't nail it down. Or appear as if you can nail it down by these very precise criteria that say it is a spectrum and you move along the spectrum.

\section{References}

Anthony, W. A. (1993). Recovery from mental illness: the guiding vision of the mental health service system in the 1990s. Psychiatric Rehabilitation Journal, 16(4), 11-23.

Davidson, L., Tondora, J., O'Connell, M. J., Bellamy, C., Pelletier, J. F., DiLeo, P., \& Rehmer, P. (2016). Recovery and Recovery - Oriented Practice. In S. C. 


\section{ARTIGOS}

Jacobs, \& J. L. Steiner, Yale textbook of public psychiatry. New York, NY: Oxford University Press.

Deegan, P. (1988). Recovery: the lived experience of rehabiiitation. Psychiatric Rehabilitation Journal, 11(4), 11-19.

van Os, J. (2016). "Schizophrenia” does not exist. British Medical Journal, 352, i375. Published 2016 Feb 2. doi:10.1136/bmj.i375.

van Os, J. (2019, 18 May). Technical psychology and psychiatry: everything under control? (Lecture). Health, Behaviour and Society, Faculty Social \& Behavioural Sciences Conference at the University of Amsterdam. Amsterdam, NL.

van Os, J. et al. (2015, March 6). Laten we de diagnose schizofrenie vergeten. NRC Handelsblad. <https://www.nrc.nl/nieuws/2015/03/07/laten-we-de-diagnoseschizofrenie-vergeten-1472619-a653133>.

van Os, J., \& Guloksuz, S. (2017). A critique of the "ultra-high risk" and "transition" paradigm. World Psychiatry, 16, 200-206. doi:10.1002/wps.20423.

van Os J., Guloksuz S., Vijn T.W., Hafkenscheid A., \& Delespaul P. (2019). The evidence-based group-level symptom-reduction model as the organizing principle for mental health care: time for change? World Psychiatry, 18(1), 88-96. doi:10.1002/wps.20609.

\section{Resumo}

(Para além do diagnóstico psiquiátrico e do modelo médico, na busca pelo "recovery" social: uma entrevista com Jim van Os)

Há uma crescente percepção no campo da psiquiatria de que somos incapazes de nos liberar das restrições impostas pelos conceitos do campo, bem como ir além deles. Assim, o campo demanda não somente evidências empíricas mais robustas, mas também um quadro de referências conceituais que permita um pensamento crítico e inovador que conceba e construa modelos mais apropriados de cuidado à saúde mental. Nesse espírito, apresentamos uma entrevista provocativa com o psiquiatria holandês Jim van Os, abrangendo desde questões sobre sua formação acadêmica até suas ideias sobre recovery e sobre a experiência dos recovery colleges na Holanda como "um sistema de saúde mental invisível”. Adotando uma posição crítica sobre o diagnóstico psiquiátrico e a validade das comparações grupais preconizadas pela medicina baseada em evidências, e em sintonia com o movimento conhecido como recovery, van Os destaca que o processo de cura deve ir além da redução de sintomas. Para ele, é preciso levar em conta o longo processo de desenvolvimento de resiliência, aprendendo com os outros a lidar com o sofrimento, 
e construindo novas perspectivas, objetivos e propósitos existenciais. Em outras palavras, a ênfase recai sobre a ideia de social recovery e favorece a ideia de que profissionais de saúde mental devem "ajudar as pessoas a se relacionarem melhor com suas variações psicológicas e oferecer a elas formas diferentes de chegar até isso."

Palavras-chave: Psicose, abordagem dimensional transdiagnóstica, social recovery, recovery colleges.

(Au-delà du diagnostic psychiatrique et du modèle médical vers le social recovery : un entretien avec Jim van Os)

Il y a une perception croissante dans le champ de la psychiatrie selon laquelle nous ne sommes pas en mesure de nous libérer des contraintes imposées par les concepts de ce domaine, encore moins de les dépasser. Ainsi, le champ de la psychiatrie exigerait non seulement des évidences empiriques plus solides, mais aussi un cadre de références conceptuelles procurant une pensée critique et novatrice capable de concevoir et de construire des modèles plus appropriés aux soins de santé mentale. Dans cette démarche, nous présentons un entretien provocateur avec le psychiatre néerlandais Jim van Os, couvrant des questions sur son parcours universitaire, ainsi que ses idées sur le recovery, et sur l'expérience des recovery 812 colleges aux Pays-Bas en tant que "système de santé mentale invisible ". C'est en adoptant une démarche critique à l'égard du diagnostic psychiatrique et de la validité des comparaisons de groupes préconisées par la médecine fondée sur les preuves et en accord avec le mouvement connu sous le nom de recovery que van os souligne que le processus de guérison doit aller au-delà de la réduction des symptômes. Pour lui, il faut prendre en compte le long mouvement de développement de la résilience, de sorte à apprendre d'autrui comment faire face à la souffrance, pour construire de nouvelles perspectives, de nouveaux objectifs et de nouvelles finalités existentielles. Ses contributions soulignent le concept de social recovery et favorisent l'idée selon laquelle les professionnels de la santé mentale devraient «aider les gens à mieux gérer leurs variations psychologiques et leur proposer différentes façons d'y parvenir».

Mots clés: Psychose, l'approche dimensionnelle transdiagnostique, social recovery, recovery colleges

(Más allá del diagnóstico psiquiátrico y del modelo médico hacia en la búsqueda del social recovery: una entrevista con Jim van Os)

Hay una percepción creciente, en el campo de la psiquiatría, de que somos incapaces de librarnos de las restricciones impuestas por los conceptos del campo, así como también de ir más allá de ellas. Por lo tanto, el campo demanda 


\section{ARTIGOS}

no solamente evidencias empíricas más robustas, sino un marco de referencias conceptuales que permita un pensamiento crítico e innovador que conciba y construya modelos más apropiados de cuidado de la salud mental. En ese sentido, presentamos una provocadora entrevista con el psiquiatra holandés Jim van Os, abarcando, desde cuestiones sobre su formación académica hasta sus ideas sobre recovery y la experiencia de los recovery colleges en Holanda como "un sistema de salud mental invisible". Adoptando una postura crítica sobre el diagnóstico psiquiátrico y la validez de las comparaciones grupales defendidas por la medicina basada en evidencias, y alineado con el movimiento conocido como recovery, van Os destaca que el proceso de curar debe ir más allá de la reducción de los síntomas. Para él, es necesario considerar el largo proceso de desarrollo de la resiliencia, aprendiendo a lidiar con el sufrimiento a través de la interacción con los otros y construyendo nuevas perspectivas, objetivos y propósitos existenciales. En otras palabras, el énfasis recae sobre la idea del social recovery, favoreciendo la noción de que los profesionales de la salud mental deben "ayudar a las personas a relacionarse mejor con sus variaciones psicológicas y ofrecerles diferentes formas para llegar a ello".

Palabras clave: Psicosis, enfoque transdiagnóstico dimensional, social recovery, recovery colleges

Citação/Citation: Zorzanelli, R., \& Banzato, C. E. M. (2020, dezembro). Moving beyond psychiatric diagnosis and the medical framework towards social recovery: an interview with Jim van Os. Revista Latinoamericana de Psicopatologia Fundamental, 23(4), 792-814. http:// dx.doi.org/10.1590/1415-4714.2020v23n4p792.7.

Editoras/Editors: Profa. Dra. Erotildes Leal Maia e Profa. Dra. Ilka Ferrari

Submetido/Submitted: 14.6.2020 / 6.14.2020 Revisado/Revised: 22.7 .2020 / 7.22.2020

Aceito/Acepted: $22.7 .2020 / 7.22 .2020$

Copyright: (C) 2009 Associação Universitária de Pesquisa em Psicopatologia Fundamental/ University Association for Research in Fundamental Psychopathology. Este é um artigo de livre acesso, que permite uso irrestrito, distribuição e reprodução em qualquer meio, desde que o autor e a fonte sejam citados / This is an open-access article, which permits unrestricted use, distribution, and reproduction in any medium, provided the original authors and sources are credited. 
Financiamento/Funding: Este trabalho não recebeu apoio / This work received no funding..

Conflito de interesses/Conflict of interest: Os autores declaram que não há conflito de interesses. / The authors declare that there is no conflict of interest.

\section{RAFAELA T. ZORZANELLI}

Psychologist; Associate Professor: Institute for Social Medicine, State University of Rio of Rio de Janeiro - UERJ (Rio de Janeiro, RJ, Br).

Rua São Francisco Xavier, 524, Pavilhão João Lyra Filho, $7^{\circ}$ andar /blocos D e E, e $6^{\circ}$ andar / bloco E - Maracanã

20550-013 Rio de Janeiro, RJ, Br

rtzorzanelli@gmail.com

https://orcid.org/0000-0001-7531-8492

\section{Claudio E. M. Banzato}

Professor of Psychiatry; Medical School, University of Campinas - Unicamp (Campinas, $\mathrm{SP}, \mathrm{Br}$ ).

Rua Tessália Vieira de Camargo, 126

Cidade Universitária “Zeferino Vaz" - Barão Geraldo

13083-887 Campinas, SP, Br.

cbanzato@unicamp.br

https://orcid.org/0000-0002-8556-3982

This is an open-access article, which permits unrestricted use, distribution, and reproduction in any medium for non-commercial purposes provided the original authors and sources are credited. 